\title{
PELATIHAN BUDIDAYA MAGOT SEBAGAI ALTERNATIVE PAKAN TERNAK DI DESA BATURONO LAMONGAN
}

\author{
Fita Faridah ${ }^{1}$, Puguh Cahyono ${ }^{2}$ \\ ${ }^{1}$ Jurusan Teknik Informatika, Fakultas Teknik, Universitas Islam Lamongan \\ ${ }^{2}$ Jurusan Managemen, Fakultas Ekonomi, Universitas Islam Lamongan \\ J1. Veteran No. 53 A Lamongan \\ $\underline{\text { fitafaridah@unisla.ac.id }}^{1}$, puguhcahyono1234567890@gmail.com ${ }^{2}$
}

\begin{abstract}
ABSTRAK
Permasalahan baru yang harus dihadapi oleh para peternak yaitu meningkatnya harga pakan ternak, sehingga membuat peternak harus mencari alternative lain untuk menekan biaya pakan, budidaya maggot solusi yang tepat untuk mengatasi masalah tersebut sebagai pengganti pakan ternak yang berprotein tinggi. Dalam Pengabdian masyarakat kali ini melaksanakan kegiatan pelatihan budidaya maggot sebagai alternative pakan ternak yang dilaksanakan di desa Baturono. Metode pelaksanaan dilakukan dengan cara ceramah, diskusi dan praktek. Hasil dari pengabdian ini adalah besarnya antusias masyarakat terhadap pelatihan ini dengan dibuktikan aktifnya masyarakat mengikuti kegiatan dari awal sampai akhir dan banyaknya peserta yang aktif dalam sesi diskusi dan tanya jawab. Sehingga bisa ditarik kesimpulan bahwa pelatihan budidaya maggot di desa baturono ini berlangsung sukses dan Meningkatnya pemahaman dan sikap peserta tentang pentingnya pengolahan limbah untuk budidaya Maggot sebagai alternative pakan ternak
\end{abstract}

Kata kunci: Magot, Black Soldier Fly, Alternatif pakan ternak.

\begin{abstract}
The new problem that must be faced by farmers is the increase in the price of animal feed, thus making farmers have to look for other alternatives to reduce the cost of feed, maggot cultivation is the right solution to overcome these problems as a substitute for high protein animal feed. In this community service, the Maggot cultivation training activity as an alternative to animal feed is carried out in the village of Baturono. The method of implementation is done by lecturing, discussion and practice. The result of this dedication was the amount of enthusiasm of the community towards this training by proving that the community actively participated in activities from beginning to end and the large number of participants who were active in discussion and question and answer sessions. So it can be concluded that the maggot cultivation training in the village of Baturono was a success and increased participants' understanding and attitude about the importance of waste treatment for Maggot cultivation as an alternative to animal feed.
\end{abstract}

Keywords: Magot, Black Soldier Fly, Alternative animal feed.

\section{PENDAHULUAN}

Para peternak ayam, bebek, burung hingga lele di desa baturono kecamatan Sukodadi biasanya memberi pakan ternaknya menggunakan pakan pellet, namun permasalahan baru yang muncul yaitu meningkatnya harga pakan dari tahun ke tahun sehingga membuat peternak harus mencari alternative lain untuk menekan biaya pakan, akhirnya kami mengenalkan solusi yang dihadapi para peternak dengan menggati pellet dengan makanan 
yang berprotein tinggi yaitu belatung. Mukin sebagian orang bergidik jika mendengar kata belatung namun belatung yang satu ini bukan sembarang belatung, dia mempunyai kandungan protein tinggi cocok sebagai pakan ternak alternative pengganti pellet dan belatung ini bernama maggot.

Maggot merupakan larva lalat black soldier fly atau serangga bunga, keberadaan lalat selama ini hanya dianggap sebagai hama oleh sebagian besar masyarakat. Maggot black soldier fly memiliki nama latin Hermetia illuciens $L$, termasuk kerabat lalat (keluarga diptera), tubuh dewasanya menyerupai tawon, berwarna hitam dan memiliki panjang 15-20 mm. Maggot BSF sebetulnya fase larva dari siklus hidup bsf, pada fase larva inilah yang disebut sebagai maggot/belatung bsf. Sebelum menjadi lalat dewasa, maggot bsf mengalami metamorfosa sempurna, yaitu dari telur, larva, prepupa, pupa, dan bsf. Waktu yang diperlukan dalam satu siklus hidup bsf cukup singkat yaitu sekitar 40 sd 44 hari. Tergantung pada kondisi tempat dan ketersediaan makanan.

Larva BSF atau biasa disebut maggot memiliki kandungan protein dan lemak yang tinggi, memiliki tekstur yang kenyal, dan memiliki kemampuan untuk mengeluarkan enzim alami. Sehingga bahan yang sebelumnya sulit dicerna dapat disederhanakan dan dapatdimanfaatkan oleh ikan. Selain itu maggot memiliki kandungan protein yang cukup tinggi, yaitu sekitar $42 \%$ (Saurin2005;Retnosari, 2007). Kelebihan lain yang dimiliki maggot adalah memiliki kandungan antimikroba dan anti jamur, sehingga apabila dikonsumsi oleh ikan akan meningkatkan daya tahan tubuh dari serangan penyakit bakterial dan jamur.Salah satu cara budidaya larva lalat Black soldier fly $(B S F)$ dengan menggunakan salah satu alternatif penanganan sampah organik. Hal ini diperkuat oleh Duponte (2003) yang mengemukakan bahwa bahan organik adalah media yang cocok bagi pertumbuhan larva black soldier fly.

Maggot tumbuh pada bahan organik yang membusuk seperti bangkai, buah, sayur mayur yang rusak atau yang lainnya. Apabila dalam keadaan utuh, maggot memiliki kadar protein yang tinggi yaitu sekitar $44 \%$ dan apabila telah dijadikan pellet maka kadar proteinnya menjadi $30 \%$ hingga $40 \%$. Kandungan protein pada maggot cukup tinggi yaitu

$44,26 \%$ dengan kandungan lemak mencapai 29,65\%. Nilai asam amino, asam lemak dan mineral yang terkandung didalam maggot juga tidak kalah dengan sumbersumber protein lainnya, sehingga maggot merupakan bahan baku ideal yang dapat digunakan sebagai pakan ternak alternatif. Berdasarkan hal ini, sehingga tim Pengabdian 
Kepada Masyarakat (PKM) mengadakan kegiatan Pelatihan budidaya maggot sebagai alternative pakan ternak di desa Baturono Kecamatan Sukodadi.

\section{METODE}

Kegiatan Pengabdian Kepada Masyarakat (PKM) ini bertujuan meningkatkan softskill dan hardskill sasaran kegiatan, yaitu warga Baturono kecamatan Sukodadi Lamongan. Adapun luaran kegiatan berupa pemahaman dan keterampilan sasaran kegiatan dalam budidaya maggot sebagai alternative pakan ternak. Keseluruhan kegiatan berdurasi selama 1 (satu) bulan diawali oleh survei awal untuk masukan data rancangan detail kegiatan. Kegiatan PKM ini menggunakan pendekatan bersifat persuasif edukatif untuk dengan metode ceramah, diskusi, dan praktek/ diskusi, melalui tahapan sebagai berikut:

a) Tim pengabdian melakukan survey lokasi pada bulan Juli 2019

b) Persiapan Kegiatan yang dilaksanakan oleh tim pengabdian untuk merencanakan kegiatan yang mencakup waktu, materi dan teknis pelaksanaan kegiatan

c) Konfirmasi dengan pihak pemerintah desa Baturono sebagai tempat pelaksanaan kegiatan mengenai teknis pelaksanaan, tempat, sarana prasarana dan peserta.

d) Setelah diperoleh kepastian waktu dan tempat pelaksanaan, Tim Pengabdiandibantu oleh Mahasiswa peserta KKN-BBM mengundang masyarakat khususnya untuk menjadi peserta pelatihan dengan target peserta 30 orang.

e) Pelaksanaan pembukaan pelatihan dibuka oleh Bapak Kepala Desa dan Ketua Pelaksana tim pengabdian Puguh Cahyono, MM dan Fita Faridah, M.Pd.

f) Kegiatan pertama pelatihan adalah dengan metode ceramah yang digunakan untk membekali para peserta pelatihan dengan menumbuhkan motivasi peserta akan pentingnya pemanfaatan limbah organic untuk sebagai alternative pakan ternak.

g) Metode caramah digunakan untuk memberikan pengetahuan dan pemahaman tentang pengertian dan konsep dasar terkait budidaya maggot, selain itu metode ini juga digunakan untuk mengenalkan Teknik- Teknik budidaya maggot.

h) Selanjutnya dalam pelatihan ini peserta diajak berdiskusi dan brainstorming untuk mampu melahirkan ide serta gagasan kreatifnya dengan melihat beragam potensi di desa Baturono. 
i) dan tahapan terakhir adalah praktek pembuatan kendang untuk tempat budidaya maggot dan sekaligus cara pembuatan maggot dari limbah organik.

\section{HASIL DAN PEMBAHASAN}

Pada tahap awal kegiatan Pegabdian Pada Masyarakat ini, kami berkunjung ke Desa Baturono menemui masyarakat yang ada di sekitar. Dalam pertemuan itu dihasilkan beberapa hal, diantaranya, bersepakat untuk mengadakan kegiatan Pelatihan Budidaya Maggot sebagai alternative pakat ternak karena mengingat permasalahan yang muncul bagi para peternak. Dan juga kami telah menkonfirmasi dengan pihak pemerintah Baturono terkait waktu dan tempat pelaksanaan pelatihan. Kegiatan dilaksanakan pada Senin tanggal 21 Juli 2019 bertempat di Aula Balaidesa Baturono, Lokasi ini dipilih mengingat sangat strategis karena berada di tengah- tengah area desa baturono dan dapat dijangkau oleh peserta pelatihan.

Materi disampaikan dalam bentuk ceramah dengan alat bantu powerpoint yang disajikan melalui LCD. Pada pemaparan materi ini, diarahkan pada pengenalan dan pemahaman peserta akan apa itu Lalat black soldier fly (BSF) dan bagaimana memanfaatkannya untuk menghasilkan larva maggot, juga dalam pelatihan ini menerangkan keuntungan peternak menggunakan maggot sebagai alternative pakan ternak, tidak hanya untuk peternak pemateri menyampaikan larva maggot juga bisa dibudidayakan oleh ibu- ibu rumah tangga sebagai alternative mengurangi limbah dan sebagai pemasukan keuangan tambahan. Peserta pelatihan berjumlah 30 orang sesuai yang ditargetkan, mereka terdiri dari unsur peternak, unsur pemuda, unsur pemerintah desa, unsur ibu-ibu rumah tangga, RW, RT. Ruang pertemuan/ aula Balaidesa dipenuhi peserta. Selain peserta, pelatihan ini melibatkan 26 orang mahasiswa KKN-BBM UNISLA yang berasal dari prodi yang berbeda. Mahasiswa KKN berperan sebagai fasilitator. Antusiasme peserta mulai terlihat pada sesi ini, dimana peserta merespon dengan positif dengan melontarkan berbagai pertanyaan disela- sela pemaparan materi. Banyak hal menarik yang sebelumnya tidak mereka ketahui atau bayangkan bahwa selama ini limbah rumah tangga bisa dimanfaatkan dan menghasilkan profit sebagai tambahan pemasukan keuangan keluarga.

Materi dilanjutkan dengan memaparkan tahapan-tahapan yang harus dilakukan dalam budidaya maggot dimulai dari pemilihan sampah organic dan anorganik. Dilanjutkan penyortiran sampah organic yang memiliki kandungan protein tinggi karena untuk menghasilkan maggot yang berkualitas harus diperhatikan jenis sampah organic yang 
memiliki kadar protein bagus. Setelah itu dilanjutakn dengan cara pembuatan kandang yang bagus untuk budidaya maggot. Dilanjutkan dengan penempatan sampah dalam kendang dan cara memancing lalat BSF untuk dating ke kendang. Dan pemaparan terakhir yaitu penyortiran antara larva BSF dan non BSF.

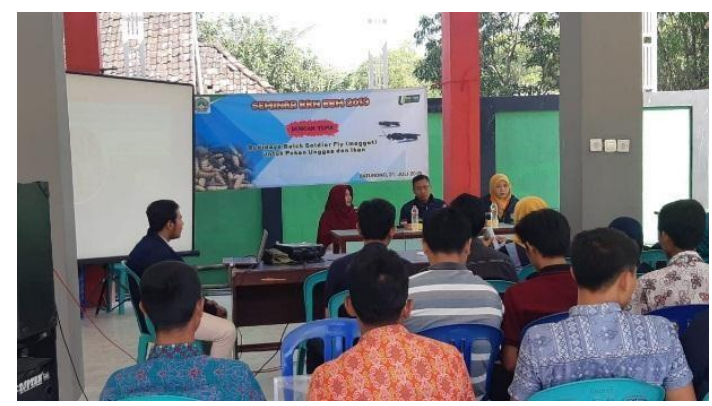

\section{Gambar 1 Pelaksananan Pelatihan Budidaya Maggot di desa Baturono}

Setelah pemaparan tentang budidaya maggot dilanjutkan sesi diskusi dan tanya jawab, pada tahap ini masyarakat sangat antusias tentang budidaya maggot yang mereka anggap sebagai alternative untuk mengatasi mahalnya biaya yang mereka khususnya peternak keluarkan untuk pemberian pakan ternak, pertanyaan tidak hanya dari para peternak juga ada beberapa ibu rumah tangga sangat antusias menanyakan budidaya maggot karena ini sangat bermanfaat bagi mereka dalam mengurangi banyaknya sampah yang terbuang dan mereka bisa memanfaatkan untuk budidaya maggot ini. Dari kalangan pemuda pun tidak ketinggalan mereka menanyakan bagaimana budidaya maggot ini bisa menghasilkan profit dan sebagai usaha yang baru untuk mereka, karena sebelumnya belum ada budidaya maggot di tempat mereka.

Dilanjutkan sesi yang terakhir yaitu praktek, dalam praktek kali ini kami tim Pengabdian Kepada Mayarakat (PKM) menggunakan sampah buah-buahan dan juga membawa contoh larva black Soldier fly, kami juga membawa miniatur kandang, dan terakhir kami mempraktekkan cara penempatan sampah dalam kendang, memberikan contoh pada masyarakat bagaimana cara pemilahan larva BSF dan non BSF karena tidak menutup kemungkinan kendang yang berisi sampah organic nanti juga akan didatangi lalat non BSF.

\section{SIMPULAN}

Setelah pelaksanaan kegiatan PKM diperoleh beberapa kesimpulan sebagai berikut:

1. Secara umum peserta pelatihan, yaitu terdiri dari unsur peternak, unsur pemuda, unsur pemerintah desa, unsur ibu-ibu rumah tangga, RW, RT mengenai budidaya Maggot sebagai alternative pakan ternak. 
2. Meningkatnya pemahaman dan sikap peserta tentang pentingnya pengolahan limbah untuk budidaya Maggot sebagai alternative pakan ternak

3. Meningkatnya keterampilan peserta terkait.

4. dengan pemanfaatan budidaya Maggot sebagai alternative pakan ternak dan keterampilan peserta dalam menuangkan gagasannya dalam bentuk lisan yang dikombinasikan dengan foto.

\section{DAFTAR PUSTAKA}

Badan Pengkajian Teknologi Pertanian [BPTP]. 2016. Teknologi pengomposan limbah organik kota dengan menggunakan black soldie _ly. Jakarta (ID): Kementerian Pertanian Republik Indonesia.

Booth DC, Sheppard C. 1984. Oviposition of the black soldier_ly, Hermetia illucens (Diptera: Stratiomyidae): Eggs, masses, timing and site characteristics. Environ Entomol 13(2): 421-3.

Darmawan M, Sarto, Prasetya A. 2017. Budidaya larva black soldier_ly (Hermetia illucens) dengan pakan limbah dapur (daun singkong). Dalam: Simposium Nasional Rekayasa Aplikasi dan Perancangan Industri (RAPI) XVI 2017. Prodising: 2018 Des 13-12; Surakarta. Surakarta (ID): Fakultas Teknik, Universitas Muhammadiyah Surakarta. p. 208-13.

Dengah SP, Umboh JF, Rahasia CA, Kowel YH. 2016. Pengaruh penggantian tepung ikan dengan tepung maggot (Hermetia illucens L.) dalam ransum terhadap performans broiler. Jurnal Zootek 36(1): 51-60. Diener S, Solano NM, Gutiérrez FR, Zurbrügg CT. 2011. Biological treatment of municipal organic waste using black soldier fly larvae. Waste Biomass Valor 2(1): 357-63.

Diener S. 2010. Valorisation of organic solid waste using the black soldier fly, Hermetia illucens L., in low and middle-income countries [Disertasi]. Diambil dari ETH Zurich.

Pangestu, widya. Universias Gajah Mada. 2017. Produksi Larva Black Soldier Fly (Hermetia illucens) dari Limbah Kulit Pisang dan Limbah Nangka Muda. Diunduh dari http://etd.repository.ugm.ac.id/

Yurie. 2019. Cara Budidaya Maggot Black_Soldier Fly Terbaru 2019. Di unduh dari Sumber Berita: https://www.vuriebsf.com/cara- budidava-maggot/

Yuwono AS. 2004. Proses pengomposan bahan organik sebagai salah satu sumber pencemaran udara. Dalam: Simposium Nasional Pertanian Organik. Prosiding: 2004 Nov 29; Bogor.

Yuwono SY, Priscilia DM. 2018. Penggunaan Larva maggot Black Soldier Fly (BSF) dalam pengolahan limbah organic. Published by Seamio Biotrop. Bogor Indonesia. 